\title{
THE ROLE OF THE INTERNET IN TOURISM - AN EXAMPLE FROM ŠUMADIJA REGION
}

\section{УЛОГА ИНТЕРНЕТА У ЕЛЕКТРОНСКОМ ПОСЛОВАҢУ У ТУРИЗМУ - ПРИМЕР ШУМАДИЈСКОГ ОКРУГА}

\author{
Nemanja Matić ${ }^{1}$ \\ Kragujevac, Srbija \\ Milan Vučetić \\ Ekonomska škola Kragujevac, Srbija
}

\begin{abstract}
The use of the Internet for the purpose of tourist destination development and improvement of tourist companies' business is getting more and more importance every day. Bearing in mind the heterogeneous character of services necessary for tourist needs, the Internet has become an integral part of establishment, delivery, and use of tourist products. From sales, as one of the most important tourist functions, through procurement and contact with clients, to marketing, as an integrative element of all other points in a tourist destination business, the Internet plays a significant role. The use of modern technologies in online business shortens the time for certain operations and lowers the business expenses.

The goal of this paper is to compare the Internet use in online business in Šumadija District and its main competitors (local and foreign). For that purpose, the following research has been conducted.
\end{abstract}

Key words: Internet, tourism, tourist destination, Šumadija District, global distribution system

Sažetak: Korišćenje interneta u svrhu razvoja turističkih destinacija $i$ unapređenja poslovanja turističkih preduzeća je od sve veće važnosti. S obzirom na heterogenost usluga koje su neophodne za zadovoljenje turističkih poreba internet je našao svoju primenu u svim delovima stvaranja, isporučivanja i korišćenja turističkog proizvoda. Krenuvši od prodaje kao jedne od najznačajnijih funkcija u obavljanju turističke delatnosti, nabavke, kontakta sa klijentima, pa do marketinga, kao integrativnog elementa svih ostalih funkcija poslovanja turističke destinacije, internet igra veoma značajnu ulogu. Korišćenje savremene tehnologije kroz elektronsko poslovanje skraćuje vreme određenih operacija i snižava troškove poslovanja.

Cilj ovog rada je da se izvrši poređenje korišćenja interneta u vezi sa elektronskim poslovanjem na nivou Šumadijskog okruga u odnosu na konkurente (domaće $i$ inostrane). U tu svrhu je izvršeno istraživanje koje je podrazumevalo anketiranje turista na području Šumadijskog okruga.

Ključne reči: Internet, turizam, turistička destinacija, Šumadijski okrug, globalni distributivni sistem

\footnotetext{
${ }^{1}$ nemanja.matic.11@ singimail.rs
} 


\section{INTRODUCTION}

Global economic crisis, together with other crisis factors directly or indirectly affecting the world economy, has contributed to the use of modern communication and information systems in all fields of economy, particularly in tourism. In order to facilitate their business, tourist destinations have placed a huge portion of their business on the Internet acquiring data on a tourist demand, informing current and potential tourists on a tourist destination or making tourist arrangements. The Internet has beneficial effects on economy, as it spreads the information, stimulates innovations, builds networks, generates capital, develops job market, facilitates tourist competition, and helps companies gain profit in various markets (Ying Chu, S. 2013). Tourists have become attached to social media, especially blogs, social networks, virtual communities, and files shared on YouTube (Xiang, Gretzel, 2010).

If tourist stakeholders in Serbia want to be competitive on regional, and particularly on European tourist markets, they will have to follow all the changes in technology, Internet development, and especially software and portals related to tourist service providers.

Bearing in mind the importance of the Internet use, the aim of this paper is to compare the levels of the Internet use in online business in Sumadija District with the selected destinations sharing similar characteristics.

\section{LITERATURE}

The number of the Internet users is constantly increasing. Nowadays, there are more than 3,3 billion users or more than $40 \%$ of the world's population, and in 1995 only 1\% were using the Internet (http://www.internetlivestats.com ). Likewise, from the mid-90s of XX century to the present, the Internet speed has increased by $50 \%$ each year (Veinović, Jevremović 2013). Our country has also witnessed an increase in the number of Internet users, so according to the data provided by the web page http://www.internetlivestats.com, in 2015 that number was around 4,76 million of Serbian citizens or $54 \%$ of the whole Serbian population.

On the Competitiveness Index of countries as tourist destinations, published every two years by the World Economic Forum (WEF), Serbia has been ranked 56 (out of 141 countries), according to the criteria related to information and communication technologies (ICT). Within the index, Serbia is in the 88th position according to the use of ICT in B2B transactions, 95th according to ICT in $\mathrm{B} 2 \mathrm{C}$ transactions, and 65th 
according to the percentage of population using the Internet (WEF 2015. 412). The abovementioned results are much better than a majority of other indicators that this institution used to rank Serbia as tourist destination because, according to overall results, Serbia has been placed in 95th position (out of 141 countries).

The Internet has found its use in tourism. It particularly refers to online sales of tourist arrangements and accommodations, promotions and informing tourists on tourist attractions, restaurants, information centers, and online payments (Buhalis, Hyun Jun, 2011). In order to satisfy the tourists' needs, tourist industry has to collect information on customers, their demands, complaints, characteristics, etc. For that purpose, information systems need to be established, which once again proves the significant role of the internet.

\subsection{Online tourist sales and procurement}

It becomes more and more difficult for traditional travel agents to compete with web sites that offer online booking possibilities. One of the main reasons for the increasing number of people booking online is that online experience has much greater potential in visualising travel destinations (Bogdanovych, Berger, Simoff, Sierra 2006.). The most important online tool for booking and sales in tourism were CRS (Computer Reservation System) or GDS (Global Distribution System). GDSs have served as the nexus of electronic commerce in travel for decades, providing virtual real-time connectivity between thousands of suppliers of travel inventory (airlines, hotels, car rental, tour operators, cruise lines, etc.) and hundreds of thousands of retail sellers of travel products (Sismanidou, Palacios \& Tafur 2009). GDS facilitates the main needs of consumers for easy and transparent access to a wide range of information regarding manners of traveling, accommodation, luxury services, valid prices and the availability of these services (Sion, Mihălcescu \& Mărginean, 2013). The best way to perceive the importance of GDS is to see the principal tasks of GDS Amadeus: (Radulović, 2013.)

- Liaising with the travel agency through which they allow a quick and efficient reservation and services sales;

- Liaising with the airlines with the aim of effective occupancy of its capacity;

- Including Hotel Amadeus system to facilitate increased sales of hotels;

- The inclusion of rent-a-car company with the aim of expanding the network services

- Providing information center related to innovation and training,

Vol. 19, број 1/2017, стр. 17-34 
- Providing commercial and technical support to all customers.

CRS can provide important strategic tools for firms and destinations while autonomous business strategies are being formed (Sion, Mihălcescu \& Mărginean, 2013).

Apart for computer systems and software for booking and sales of tourist arrangements, there is a large number of websites and mobile phone apps providing tourists with online booking and other services such as www.booking.com, www.hotels.com, ebooking.com, etc. The thirdparty OTAs that have grown up to serve the hotel industry are organizations that have no physical outlets but provide their services solely through the internet. Familiar examples include Expedia.com, Orbitz.com, Priceline.com, and Travelocity.com (Lee, Guillet, Low 2013.). From 2008. to 2012, online booking increased from 266 to 374 billion dollars, and it is estimated that in 2016 the amount could be even higher than 500 billion dollars (Kayani, 2014).

The online sale of transportation services is particularly important. Bearing in mind that in 2014, tourists reached their destinations by plane $(54 \%)$, by road $39 \%$, and by train $2 \%$ (UNWTO 2015), it seems that the focus should be on booking tickets in air transport. Nowadays, most of airlines provide online booking, ticket issuing, flight information, various prices, etc. (Ivanović, Gašić, Simić, 2016). GDSs, progressively consolidated their position to only four major systems, namely Sabre, Amadeus, Galileo and Wordspan (the two latter now both acquired by Travelport, Inc.) (Sismanidou, Palacios \& Tafur 2009) ${ }^{2}$. All of them cover 95\% of the market. The data referring to 2014 show that Amadeus covered 40,7\% of the market (Maroto, 2015), Sabre 35,7\% (Klein, Simonson, 2015), while Travelport did not state its share in the report. Keeping in mind that Sabre's income amounted to 2,63 billion dollars and Travelport 2,15 billion, we can conclude that Travelport has a smaller share than Sabre (www.tnooz.com). Several studies (Sam, Tahir, 2009) have listed the qualities of a website influencing the tourists decision to buy plane tickets: usage, web design, information accuracy, trust, risk perception, and empathy. We should also mention the mobile phone app Skyscanner, enabling flight search according to various criteria.

Procurement, as a function in the business of tourist service providers, has a huge importance since it affects the creation and sales of tourist products. The basic input for tourist and catering capacities

\footnotetext{
${ }^{2}$ Amadeus as GDS is present in 195 zemalja, 693 airlines, 116 insurance companies, more than 87.000 hotels, 30 rent-a-car agencies, 206 tour operators and 102 train companies. (https://www.amadeus.net)
} 
includes food and beverage preparation, gas, office supplies and marketing, cleaning products, and maintenance.

E-procurement means purchasing goods and services over the Internet. Its further goal is to move the entire procurement process online, bringing operators together with their chosen distributors and enabling a streamlined and automated flow of the purchasing cycle (Ivanovska, 2007). E-Procurement's benefits include: lower administration costs, inventories, and purchasing prices; shorter order cycle time; enhanced cooperation with suppliers, performance, and multichain operations (Sigala, 2006). The adoption of e-procurement in the hotel industry has been surprisingly low, despite its huge potential (Au, Hoc, Low, 2014).

Hotels typically have different IT systems in individual departments, such as the Point of Sales (POS) for food and beverage departments, accounting systems for accounting departments, and reservation systems for the front office (Au, Hoc, Low, 2014). Aside from POS, another useful tool for e-procurement is PMS (property management systems). Hotel managers claimed that the major benefits of using front office systems and PMS are: increasing the efficiency and accuracy of internal information transmission; saving the costs of paper work and information-processing labour; and increasing the effectiveness of management, especially in terms of cash, account, stock and yield management (Xiaoqiu, Buhalis, Song, 2003).

\subsection{Online marketing in tourism}

A database with the history of all online transactions may be the main source of marketing information for tourism companies, deciding what type of tourism products they may offer, what market segment they address better and how the company is rated by consumers (Sion, \& Mihălcescu, 2011). It should be pointed out that the influence of the Internet on marketing and making of marketing mix is manifold: (Yannopoulos, 2011)

- Influence on a product and branding (software and digital products),

- Influence on price policy (it broadens information and interactive relation with the buyers, increases the number of suppliers and enables easier market research),

- Influence on distribution (it increases the consumers' trust, facilitates the delivery of services, changes the cost structure, enables the information distribution through the computers on the network, diminishes the distance between buyers and sellers, enables the purchase at any time), 
- Influence on the marketing (web pages and e-mail).

The main forms of online marketing are online advertisements and public relations. Online advertising includes (Klapdor, 2013, pp 17):

- marketing on the Internet browsers (optimization of websites in order for them to be more visible on Google, Yahoo, and many others),

- banners (places on websites leading to new websites or online advertisements),

- $\boldsymbol{e}$-mail (emailing the links to potential buyers so that they could visit a company's website or another web content),

- affiliate marketing (some companies pay other ones to lead potential buyers to their websites),

- mobile phone advertisements (marketing messages sent to mobile phones),

- classifieds and directories (online marketing in which the consumers or companies pay certain fees to gather specific information),

- sponsorship (connecting brands with online content in order to increase the visibility of the brand).

Online public relations include (Klapdor, 2013, pp 23):

- Online news feeds (news on websites about companies),

- Social media marketing (blogs, social networks, etc.),

- Link building (increase in website ranks by attracting a large number of links from other web pages),

- Viral marketing (marketing by word of mouth).

To satisfy that demand, tourism firms of all sizes may need to expand their traditional marketing channels (for example brochures, billboards and stands at trade shows) and their conventional tourism product distribution channels (such as the use of travel agents, destination marketing organisations and travel wholesalers) to include the Internet for business-to-consumer (B2C) interaction (Braun, 2005.). The ease of use, interactivity and flexibility of Web-based interfaces suggests an allied and important role for World Wide Web technology in destination marketing, and indications are that tourism Websites are constantly being made more interactive (Doolin, Burgess, Cooper, 2002). ICTs allow direct and interactive relationships between tourism organizations and customers. CRM initiatives enable enterprises to identify the individualized needs of their customers and match them with satisfying tourism product offerings (Stiakakis, Georgiadis 2011). 
Nowadays, many firms, not only the ones related to tourism, use CRM (customer relationship management), that is, the management of the relations with buyers which entails: "set of processes, usually linked to a database, that help an organization keep in contact with customers and deal with their requests, complaints, suggestions and purchase" (Smith, Zook, 2011). A successful CRM needs: (Smith, Zook, 2011)

- CRM architecture (skilled management, business management and their analysis, consumers' feedback, applications transforming call centers into interactive contact centers, etc.),

- processes (profiling or defining the buyers' clear profile, contact adapting strategy, management database).

- credibility factors (one needs to have a quality product and service, and to provide buyers with an easy access, effective contact, swift content download...).

The presence on the Internet and interactivity have a considerable impact on CRM (in terms of partnership, growing, communication with buyers, and personalization) and buyers' loyalty. Tourist managers can adapt their future strategies to buyers' needs and create an effective offer and service (Corigliano, Baggio, 2004). SCRM (Social customer relationship management) has been in focus recently as it entails that companies use social media as a marketing technique while interacting with a client (Elena, 2015).

One should particularly point out Web 2.0 System for information and presentation of tourist destinations, including online content accessible in audio and video formats, blogs, social network information and online encyclopedias (Sharda, 2010).

\subsection{Other types of online business in tourism}

Apart from its use in tourist sales, procurement, and marketing, the Internet can be used in many other fields not necessarily related to tourism. Global information system (GIS) can be a good example, especially in managing a tourist destination, helping tourists in the fields not related to tourism, and as a significant information source useful in tourist offers and tourist destination management. It is a database providing a visual data (maps) based on which numerous analyses could be conducted. In the tourism industry, GIS is used to provide: (Jovanović, Njeguš 2008.)

- A digital map base for printed maps,

- Digital files for Internet mapping,

- Digital files for mobile mapping,

- Attractions map, 
- Website with interactive mapping.

Use of GIS in tourism can be: visitor flow management (this involves the use of GIS to identify principal tourist activity spaces within a destination and the flows among destinations), facility inventory and resource use, assessing impacts of tourism development, GIS applications in retail tourism, evaluation of the site selection... (Chen, 2007). On the other hand, tourists use GIS so that they could obtain data related to demographics, weather, infrastructure, road and railway network, tourist attractions, hotels, metro stops, etc.

2. Tourists can use the Internet to perform online banking transactions (payments and currency conversions). Many banks operate according to the "click-and-mortar" principle (directly communicating with the clients online), and also there are internet-only banks (De Young, 2005).

3 . One of the features of social networks, where tourists share their opinions on tourist destinations, is a „TripAdvisor effect” (Čačić, Mašić, 2013). On that website and similar portals, managers can see tourists' opinion on tourist capacities, their complaints about the service, and correct the mistakes so that they could satisfy the tourists' needs. The websites such as Tripadvisor.com and travelpod.com enable their users to exchange information, opinions, and recommendations about tourist destinations, sometimes providing trip diaries or ranking particular products and hotels (Akehurst, 2009). Social networks are particularly important for tourist business development, as it is estimated that $32.7 \%$ of the entire world's population and $70.8 \%$ of the Internet users will have a social network profile in 2018 (Ilić, Marković 2016). Social media plays an increasingly important role in many aspects of tourism, especially in information search and decision-making behaviours and tourism promotion focusing on best practices for interacting with consumers via social media channels (social sharing of holiday experiences) (Zeng, 2013). Some social media designed for travelling are becoming more and more popular, and they will probably evolve into a primary source of information related to travelling (Milano, Baggio, Piattelli, 2011). Modern tourists trust other tourists more than official marketing advice (Živković, Gajić, Brdar, 2014). The content on blogs can: 1) attract attention of other Internet users and increase the visits to a website, 2) create users' interest, 3) increase the wish to visit a destination, and 4) encourage action (to book a hotel or organize a visit to a destination) (Sigala, 2007). Certain types of crises require the contribution by and coordination of different stakeholders and/or volunteered action and resources, and so, the mass collaboration and networking capabilities of social media can substantially support such crisis management practices 
(Sigala, 2011). One of the benefits of social media is that DMOs (destination management organizations) can cooperate and facilitate information, adding the value for consumers and building their brand through a direct interaction with the consumers (Faria, Elliot, 2012). During its development, the Web has undergone several stages, from Web 1.0 (Individual Intelligence - until 1999.), through Web 2.0 (Collective Intelligence - from 2000 until 2009.), to Web 3.0 (Knowledge Internet from 2010.) (Jovanović-Tončev, Podovac, 2016). In recent years, a Travel 2.0 concept has appeared; it is an extension of Web 2.0 concept (cooperation and interaction of the Internet users - social networks, blogs, websites for picture and video posting...). Travel 2.0 is described as a new generation of travelling websites, enabling social collaboration among tourists, as they can share their travel experiences (Rathonyi, 2013).

We can mention another useful tool in tourism (especially for DMOs - Destination Management organizations) called Destination Management Systems (DMS). Destination Management Systems (DMS) are systems that consolidate and distribute a comprehensive range of tourism products through a variety of channels and platforms, generally catering for a specific region, and supporting the activities of a destination management organisation (DMO) within that region (Frew, \& Horan, 2007). DMSs are employed by many national and regional governments to facilitate the management of DMOs, as well as for the coordination of local suppliers at the destination level (Buhalis, Leung, Law, 2011).

\section{INTERNET IN ŠUMADIJA REGION TOURISM}

In order to determine the use of the Internet for tourist purposes in Šumadija District, we conducted a research which included the polling of tourists in hotels in that area (in the municipalities of Kragujevac, Aranđelovac, and Knić) from January to March 2015. In total, 114 tourists were polled, 75 locals and 39 foreigners.

The tourists in the specified hotels were asked 20 questions that could be divided into three groups.

The first group refers to tourists' basic characteristics such gender, origin (whether they are locals or foreigners), age, education, and the reason of visiting this tourist destination. Based on the results, we can conclude that men and women were equally represented in the questionnaire. Local tourists comprised 64\%, whereas the foreigners comprised $36 \%$. As regards their age, the tourists between 25 and 40 years of age were $41,2 \%$, whereas the ones from 40 to 55 years of age were $33,3 \%$. The tourists from 55 to 65 years of age comprised a high 
percentage too $(13,2 \%)$. The tourists above 65 years of age comprised $4,4 \%$.

As regards the tourists' educational structure, we can conclude that educated people were a predominant profile. The largest number of the polled tourists said that they had a university degree $(36 \%)$, whereas those ones with a college degree (two years of studies) were $22,8 \%$. The tourists with a high school education comprised $21,9 \%$. The ones with a master's degree were $10,5 \%$. It is interesting that $7 \%$ of the tourist claimed to have a doctoral degree. It means that $76,3 \%$ of the polled tourists had a higher education degree.

In terms of reasons for visiting Šumadija District, the largest number of tourists $(50,9 \%)$ said that they had come to the District for business. On the other hand, $22,8 \%$ of the polled tourists came to Kragujevac and Šumadija District due to various events (fairs, conferences, etc.) or to what is usually called MICE tourism. Vacation was the main reason for $18,4 \%$ of tourists, while only $1,8 \%$ of them came because of medical treatment. The fact that not many tourists were polled in Aranđelovac Municipality contributed to a relatively small number of spa tourists in the questionnaire.

The following group of questions referred to the use of the Internet for tourist purposes. After collecting the answers, preliminary statistical research was conducted based on which a further analysis can be made.

Table 1.: Indicators of the Internet use for tourist purposes

\begin{tabular}{|l|l|l|l|l|}
\hline No. & Indicators of the Internet use for tourist purposes & No & AM & SD \\
\hline 1 & How often do you use the Internet? & 114 & 3,74 & 0,95 \\
\hline 2 & $\begin{array}{l}\text { How often do you use the Internet to decide on a tourist } \\
\text { destination? }\end{array}$ & 114 & 3,40 & 1,07 \\
\hline 3 & $\begin{array}{l}\text { How often do you use the Internet to be informed on the } \\
\text { destination you are visiting? }\end{array}$ & 114 & 3,64 & 1,02 \\
\hline 4 & $\begin{array}{l}\text { How much do social networks, forums, blogs, and tourist } \\
\text { websites influence your decision to choose a hotel, } \\
\text { destination, etc. (TripAdvisor, Booking.com...) }\end{array}$ & 114 & 3,17 & 1,10 \\
\hline 5 & $\begin{array}{l}\text { How often do you comment on hotels and destinations on } \\
\text { those websites? }\end{array}$ & 114 & 2,56 & 1,33 \\
\hline 6 & $\begin{array}{l}\text { How much do you use the Internet to book a hotel, purchase } \\
\text { ticket for events or tourist attractions? }\end{array}$ & 114 & 3,09 & 1,34 \\
\hline 7 & $\begin{array}{l}\text { How much do you use mobile phone apps for searching the } \\
\text { tourist attractions, streets, hotels, etc.? }\end{array}$ & 114 & 2,75 & 1,32 \\
\hline
\end{tabular}

\section{Source: Autors research}

Based on the results of the research, it can be noted that the highest arithmetic mean 3,74 was with the answers related to the Internet 
use, whereas the lowest 2,56 was with the answers related to commenting on the quality of hotels, tourist attractions, and destinations in general on social networks. Likewise, based on the arithmetic means, we can conclude that tourists extensively use the Internet to get informed about the destination they are visiting (question 3 had 3,64 arithmetic mean) and the choice of destination (question 2 had 3,40 arithmetic mean). In questions 6 and 7, if we analyze the arithmetic mean, we can argue that the polled tourists used the Internet less for booking the rooms and purchasing the tickets for events and tourist attractions (arithmetic mean was 3,09) and for using mobile phone apps in order to find tourist attractions, streets, and hotels $(\mathrm{AM}=2,75)$. The highest degree of agreement was with the questions referring to the use of the Internet and getting informed about a tourist destination the tourists are visiting (questions 1 and 3) where there was the lowest standard deviation.

Table 2.: Indicators of the Internet use for tourist purposes in Šumadija District

\begin{tabular}{|c|c|c|c|c|}
\hline No. & $\begin{array}{c}\text { Indicators of the Internet use for tourist purposes } \\
\text { in Šumadija District }\end{array}$ & No & $\mathbf{A M}$ & SD \\
\hline 1 & $\begin{array}{l}\text { How much did you use the Internet to inform } \\
\text { yourself about Kragujevac/Šumadija District? }\end{array}$ & 114 & 2,87 & 1,101 \\
\hline 2 & $\begin{array}{l}\text { How much did social networks, forums, blogs, and } \\
\text { tourist websites (TripAdvisor, Booking.com...) } \\
\text { influence your decision to choose a hotel, } \\
\text { destination, etc. in Kragujevac/ Šmadija District? }\end{array}$ & 114 & 2,63 & 1,192 \\
\hline 3 & $\begin{array}{l}\text { How much do you visit (or did you visit) the web } \\
\text { presentation of Kragujevac Tourist Organization? }\end{array}$ & 114 & 2,19 & 1,330 \\
\hline 4 & $\begin{array}{l}\text { How much do you visit (or did you visit) websites } \\
\text { of the hotels in Kragujevac/Šumadija District? }\end{array}$ & 114 & 2,75 & 1,181 \\
\hline 5 & $\begin{array}{l}\text { How much did you use the Internet to inform } \\
\text { yourself about a tourist offer or a landmark in } \\
\text { Kragujevac/Šumadija District? }\end{array}$ & 114 & 2,76 & 1,115 \\
\hline 6 & $\begin{array}{l}\text { How much did you use Google Earth or a similar } \\
\text { application to find a street/hotel/landmark in } \\
\text { Kragujevac/Šmadija District? }\end{array}$ & 114 & 2,74 & 1,269 \\
\hline 7 & $\begin{array}{l}\text { How do you see the quality of the web tourist } \\
\text { presentation of Kragujevac/Šumadija District? }\end{array}$ & 114 & 2,70 & 1,120 \\
\hline
\end{tabular}

Source: Autors research

The first question in the questionnaire on the tourism in Šumadija District referred to the Internet use for the purpose of booking a hotel in this tourist destination. The results of the research show that $61,4 \%$ (or 70 polled tourists) gave a positive answer, which indicated the importance of the Internet in the tourist industry of Šumadija District. Without 
connecting to the remainder of the research, this information is not enough to make general conclusion; therefore, it is necessary to analyze the other data from the table 2.

Based on the analysis of arithmetic mean referring to the Internet use for tourist purposes in Sumadija District, we can conclude that the situation is different in comparison with the previous analysis of the general Internet use by the polled tourists, that is, the average percentages were lower. Bearing in mind the last group referring to the tourism in Sumadija District, it is easy to notice that arithmetic mean does not exceed 3, which leads to the conclusion that in this destination, the Internet use for tourist purposes was extremely low. The highest arithmetic mean was at the first question $(\mathrm{AM}=2,87)$ referring to how much the tourists used the Internet to get informed about this tourist destination. A slightly lower percentage was at the question about the informing on general tourist offer or a particular tourist attractions in Šumadija District (the arithmetic mean was 2,75), and similar results were produced at the question about the Internet use for the purpose of getting informed about the hotels in the specified destination. The arithmetic mean at the question about how much the tourists had visited the website of Kragujevac Tourist Organization was 2,19, which can be considered alarming, whereas at the question about how the tourists saw the web presentation of Kragujevac and Sumadija District, the arithmetic mean was 2,70 , based on which we can conclude that tourists did not frequently visit the web pages referring to tourist potentials of the specified area. With this group of questions we can also make conclusion based on the standard deviations mostly at questions 3 and 6 referring to the visits to the website of Kragujevac Tourist Organization and the use of mobile navigation apps for finding tourist attractions, streets, and hotels, which implies the highest degree of disagreement among the polled tourists. The biggest agreement was at questions 1 and 5 about the Internet use for the purpose of obtaining information about the tourism in Kragujevac and Sumadija District $(S D=1,101)$ and finding the tourist attractions in Kragujevac and Šmadija District $(S D=1,115)$, where there were the lowest standard deviations.

At the end of the research, a Paired samples t-test was conducted in SPSS program for several key questions in order to determine whether there was a significant difference among the arithmetic means of the specified criteria, which could indicate the difference in the Internet use for tourist purposes in Šumadija District. While polling the tourists in Šmadija District, we asked them different questions about the Internet use for tourist purposes in general and then the same questions were asked about Šumadija District. The first couple of questions in the Paired 
samples t-test referred to the Internet use for the purpose of informing about tourist destinations in general, and then the same questions were asked, but this time about Šumadija District. In table 3 we can see that the result of the test was (Sig. (2-tailed)) .000, implying that the difference between the tested variables was statistically significant. If we analyze the results from tables 1 and 2, we can see that the arithmetic mean for the first question, referring to the Internet use for the purpose of informing the tourists about a tourist destination, AM was 3,64 (question 3 in table 1), whereas with the same parameter, referring to Šumadija District (question 1 in table 2), AM was 2,87. It is obvious that tourists used the Internet more to be informed about tourist destinations in general than to get the information about Šmadija District.

Table 3.: Paired samples t-test

\begin{tabular}{|c|c|c|c|c|c|c|}
\hline \multirow{2}{*}{ Variable } & \multirow{2}{*}{ Mean } & \multirow{2}{*}{ SD } & \multicolumn{2}{|c|}{$\begin{array}{c}95 \% \text { confidence } \\
\text { interval }\end{array}$} & \multirow{2}{*}{$\mathbf{t}$} & \multirow{2}{*}{$\begin{array}{l}\text { Sig. (2- } \\
\text { tailed) }\end{array}$} \\
\hline & & & Lower & Upper & & \\
\hline $\begin{array}{l}\text { How often do you use the Internet to } \\
\text { decide on a tourist destination you are } \\
\text { visiting? - How much did you use the } \\
\text { Internet to inform yourself about } \\
\text { Kragujevac/Šumadija District? }\end{array}$ & 0,772 & 1,039 & 0,579 & 0,965 & 7,930 & .000 \\
\hline $\begin{array}{l}\text { How much do social networks, forums, } \\
\text { blogs, and tourist websites influence } \\
\text { your decision to choose a hotel, } \\
\text { destination, etc.?- How much did social } \\
\text { networks, forums, blogs, and tourist } \\
\text { websites influence your decision to } \\
\text { choose a hotel, destination in Šumadija } \\
\text { District? }\end{array}$ & 0,535 & 1,090 & 0,333 & 0,737 & 5,239 & .000 \\
\hline $\begin{array}{l}\text { How much do you use mobile phone } \\
\text { apps for searching the tourist } \\
\text { attractions, streets, hotels, etc? - How } \\
\text { much did you use Google earth or a } \\
\text { similar application to find a } \\
\text { street/hotel//landmark } \\
\text { Kragujevac/Šnmadija District? }\end{array}$ & 0,009 & 1,164 & $-0,207$ & 0,225 & 0,080 & .936 \\
\hline
\end{tabular}

The second group of tested parameters referred to the influence of websites, blogs, and social networks (such as TripAdvisor or Booking.com) on choosing a destination, hotels, and tourist attractions. The result was (Sig. (2-tailed)) .000, once again implying that the difference between the tested variables was statistically significant. We should point out the results acquired in tables 1 and 2, where the arithmetic mean for general Internet use was $A M=3,17$, and in case of Šmadija District AM was 2,63. Thus, we can conclude that the Internet, 
blogs, and social networks about tourism had much greater impact on tourists when they refer to tourist destinations in general than when they are about Šumadija District.

The last group of parameters referred to the use of mobile navigation apps which enable tourists to find hotels, tourist attractions, streets, etc. The result of the Paired samples t-test was 0,936, which is more than 0,05 , and therefore we can conclude that the difference between the arithmetic means was approximately 1 , that is, it was not significant. In tables 1 and 2, we can see that AM was 2,75 at the question referring to the use of mobile apps in general, and in case of Šumadija District AM was 2,74, which tells us that the tourists did not use the foregoing apps much for both other tourist destinations and Šumadija District.

\section{CONCLUSION}

Reading the relevant literature, we could make conclusions about the scale of the Internet use in tourism. Its use in sales, procurement, marketing, and other similar fields necessary for normal functioning of tourist destination can have a significant role in the increase of competitiveness of Šumadija District as a tourist destination. There is no need to mention the importance of the Internet on marketing, which should be the bases of all other functions. The innovations in the Internet sales should be closely followed, since the trend in this type of trade is increasing. Apart from the specified functions, the Internet has an important role in other aspects of tourism (procurement, transport, communication with tourists, etc.) and considerably facilitates the functioning of tourist destinations, providing the demanding tourists with all the services at the highest level.

On the basis of the preliminary statistical research and Paired samples t-test, it can be concluded that for the polled tourists the importance of the Internet for tourist purposes was lower for Šumadija District than in general. The arithmetic means for the parameters referring to Šumadija District were lower than the parameters referring to the general influence of the Internet on tourist trips. Likewise, based on the results of Paired samples t-test, it can be concluded that for several questions - which can indicate the Internet use for tourist purposes - the difference was significant; in other words, the Internet is used less for Šumadija District than for other destinations. All that points to the conclusion that service providers in Šumadija District have to make additional effort to increase their visibility on the Internet. The arithmetic mean referring to the assessment of the quality of Sumadija District's 
tourist presentation and the visits to Kragujevac Tourist Organization's website was extremely low, which should be considered alarming, but also it should be a signpost to all tourist stakeholders in terms of the fields where additional effort should be made to increase the tourist turnover.

\section{REFERENCES}

1. Akehurst, G. (2009). User generated content: the use of blogs for tourism organisations and tourism consumers, Service Business, 3(1), 51-61.

2. Au. N., Hoc, K.G., Low, R. (2014). Towards an understanding of e-procurement adoption: a case study of six hotels in Hong Kong. Tourism Recreation Research, 39(1), 19-38.

3. Bogdanovych, A., Berger, H., Simoff S., Sierra, C, (2006). Travel Agents vs. Online Booking: Tackling the Shortcomings of Nowadays Online Tourism Portals. In International conference", Information and Communication Technologies in Tourism 2006”, 2006 (pp. 418-428). Lausanne, Switzerland

4. Braun, P. (2005). Regional Tourism and the Internet in Australia. Encyclopedia of Developing Regional Communities with Information and Communication Technology, 603-607

5. Buhalis, D., Leung, D., Law, R. (2011). eTourism: Critical Information and Communication Technologies for Tourism. Destinations, in Wang, R., and Pizam, A., (eds), Destination Marketing and Management: Theories and Applications, CAB International, pp.

205-224. dx.doi.org/10.1079/9781845937621.0205

6. Buhalis D., Jun S. H. (2011). E-tourism. Contemporary tourism review, Goodfellow Publishers Ltd. http://www.goodfellowpublishers.com/free files/fileEtourism.pdf

7. Chen, R.J.C., (2007) Geographic information systems (GIS) applications in retail tourism and teaching curriculum. Journal of Retailing and Consumer Services, 14, 289-295

8. Corigliano, M.A., Baggio R. (2004). Tourism, technology, information and the relationship with customers. In International conference "Leisure futures", 10-12 Novembar 2004 (pp. 1- 15). Bolzano, Italy.

9. Crotti, R., Misrahi, T. (2015). (Eds.), The Travel \& Tourism Competitiveness report 2015 (pp. 292 - 293). World Economic Forum. Geneva

10. Čačić K., Mašić, S. (2013). Uticaj portala TripAdvisor na poslovajne hotela u Srbiji. Marketing, 44(3), $211-220$. 
11. DeYoung R. (2005). The performance of internet-based business models: Evidence from the banking industry. Journal of business, 78(3), $893-947$.

12. Doolin, B., Burgess, L., Cooper, J. (2002). Evaluating the use of the Web for tourism marketing: a case study from New Zealand. Tourism Management, 23, 557-56

13. Elena, C. A. (2015). Social Media - a Strategy in Developing Customer Relationship Management. In 3rd GLOBAL CONFERENCE on BUSINESS, ECONOMICS, MANAGEMENT and TOURISM, 26-28 November 2015 (pp. 785-790). Procedia Economics and Finance, Rome.

14. Faria W. L., Elliot S. (2012). Understanding the role of social media in destination marketing. Tourismos: An international multidisciplinary journal of tourism, 7(1), 193 - 211.

15. Frew, A.J., Horan, P. (2007). Destination website effectiveness: a delphi study-based eMetric approach. HITA Conference. Orlando, USA: pp. 49-80

16. Ivanović V., Gašić M., Simić J. (2016). Primena savremenih informaciono-komunikacionih tehnologija u turizmu. Anali Ekonomskog fakulteta u Subotici, 52(35), 145 - 156.

17. Ivanovska, L.P. (2007). E-procurement as an instrument for hotel supply chain management. Journal of tourism, 3, 11-15.

18. Ilić, D., Marković, B. (2016). Analiza upotrebe društvenih mreža u poslovanju, Ekonomski pogledi, 18(3), 52-67.

19. Jovanović, V., Njeguš, A. (2008).The Application of GIS and Its Components in Tourism. Yugoslav Journal of Operations Research, 18(2), 261- 272.

20. Jovanović Tončev, M., Podovac, M. (2016) Promoting Serbian spas using web sites of tourism organizations and specialized hospitals. Ekonomski pogledi, 18(2), 77-86.

21. Kayani K. (2014). Impact of internet communication technology on bricks \& mortar travel agents and changes in supply chain positioning. In R. Baggio, M. Sigala, A. Inversini, J. Pesonen (Eds.), Information and communication technologies in tourism 2014 (pp. 40 - 56). Dublin: Enter.

22. Klapdor S. (2013). Effectiveness of online marketing campaigns. Munich: Springer Gabler.

23. Klein T., Simonson R. (2015). Sabre corporation Q4 2014 earnings report, Sabre, New York. http://files.shareholder.com/downloads/AMDA2OXSEI/1731161516x0x810053/0C8D0B00-85EC-4869-89E8E393C93F28CE/SABR_Q4_2014_Earnings_FINAL.pdf 
24. Lee, A.H., Guillet, D.B., Low, R. (2013.) An Examination of the Relationship between Online Travel Agents and Hotels: A Case Study of Choice Hotels International and Expedia.com. Cornell Hospitality Quarterly February 2013, 54(1), 95-107.

25. Maroto L. (2015). Amadeus FY 2014 results, Amadeus TT Group, Madrid.

http://www.investors.amadeus.com/media/files/english/financial_r eports/quarterly_financial_info/2014/Q4\%202014/FY\%202014\% 20Results\%20Presentation.pdf

26. Milano, R, Baggio, R, Piattelli, R. (2011). The effects of online social media on tourism websites. In 18th International Conference on Information Technology and Travel \& Tourism January, 26-28 2011. ENTER, Innsbruck.

27. Radulović, LJ. (2013) The role and potential of global distribution system AMADEUS for tourism devalopement at the global level. Journal of applied sciences, 10 (1), 28-38.

28. Rathonyi, G. (2013). Influence of social media on tourism especially among students of The University of Debrecin. Applied Studies in Agribusiness and Commerce, 7(1), 105 - 112.

29. Sam M.F.M., Tahir M.N.H. (2009). Website quality and consumer online purchase intention of air ticket. International Journal of Basic \& Applied Sciences IJBAS-IJENS 9(10), 4 - 9.

30. Sharda N. (2010). Tourism informatics. Information science reference. New York.

31. Sigala, M. (2006) E-Procurement Diffusion in the Supply Chain of Foodservice Operators: An Exploratory Study in Greece. Information Technology \& Tourism, 8(2),79-90

32. Sigala, M. (2011). Social media and crisis management in tourism: applications and implications for research. Information Technology \& Tourism, 13, 1-000. DOI: http://dx.doi.org/10.3727/109830512X13364362859812

33. Sigala, M. (2009). WEB 2.0 in the tourism industry: A new tourism generation and new ebusiness models, pp. 1 - 6. ICT Working Papers. http://195.130.87.21:8080/dspace/bitstream/123456789/386/1/We b\%202.0\%20in\%20the\%20tourism\%20industry\%20a\%20new\%2 0tourism $\% 20$ generation $\% 20$ and $\% 20$ new $\% 20 \mathrm{e}-$ business $\% 20$ models.pdf

34. Sion, B. \& Mihălcescu, C. (2011). The Functionality Of The Internet As Tourism Marketing Instrument. Journal of Information Systems \& Operations Management, 5(1), 74-80 
35. Sion, B., Mihălcescu, C., Mărginean, A. (2013). The Passage from Airline Reservation Systems to Global Distribution Systems. Journal of Information Systems \& Operations Management, 7(1), $93-104$.

36. Sismanidou A., Palacios M., Tafur J. (2009). Progress in airline distribution systems: The threat of new entrants to incumbent players. Journal of Industrial Engineering and Management, 2(1), 251-272.

37. Smith P., Zook, Z. (2011). Marketing communications. London: Koganpage.

38. Stiakakis, E., Georgiadis, C.K. (2011) Drivers of a tourism ebusiness strategy: the impact of information and communication technologies. Operational Research, 11(2), 149-169

39. Yannopoulos P. (2011). Impact of the Internet on Marketing Strategy Formulation. International Journal of Business and Social Science. 2(18), $1-7$.

40. Ying C. S. (2013). Internet, economic growth and recession. Modern economy, 4(3A), $209-213 . \quad$ doi: 10.4236/me.2013.43A023

41. UNWTO Tourism highlights 2015 edition, (2015). World tourism organization, Madrid. http://www.eunwto.org/doi/pdf/10.18111/9789284416899

42. Xiang Z., Gretzel U. (2010). Role of social media in online travel information search. Tourism Management, 31(2), 179-188.

43. Xiaoqiu Ma., Buhalis, D., Song, H. (2003). ICTs and Internet Adoption in China's Tourism Industry. International Journal of Information Management, 23(3), 451-467.

44. Zeng B (2013) Social Media in Tourism. J. Tourism Hospit. 2(1), 1-2 http://dx.doi.org/10.4172/2167-0269.1000e125

45. Živković, R., Gajić, J., Brdar, I. (2014). The impact of social media on tourism. In SINTEZA: E-Business in tourism and hospitality industry, 2014 (pp. 758 - 761). Belgrade, Serbia: Singidunum university

46. https://www.amadeus.net/content/about_us

47. http://www.internetlivestats.com/internet-users

48. http://www.internetlivestats.com/internet-users/serbia

49. https://www.statista.com/outlook/243/100/ecommerce/worldwide

50. https://www.tnooz.com/article/GDS-Travelport-Sabre-Amadeus2014-earnings

Рад је примљен: 06.02.2017.

Коригована верзија примљена: 25.03.2017.

Рад је прихваћен за итампање: 05.04.2017. 